\title{
norden
}

\section{Från dröm till verklighet}

Om nordiska kompetensmål och didaktiska principer för undervisning i entreprenörskap

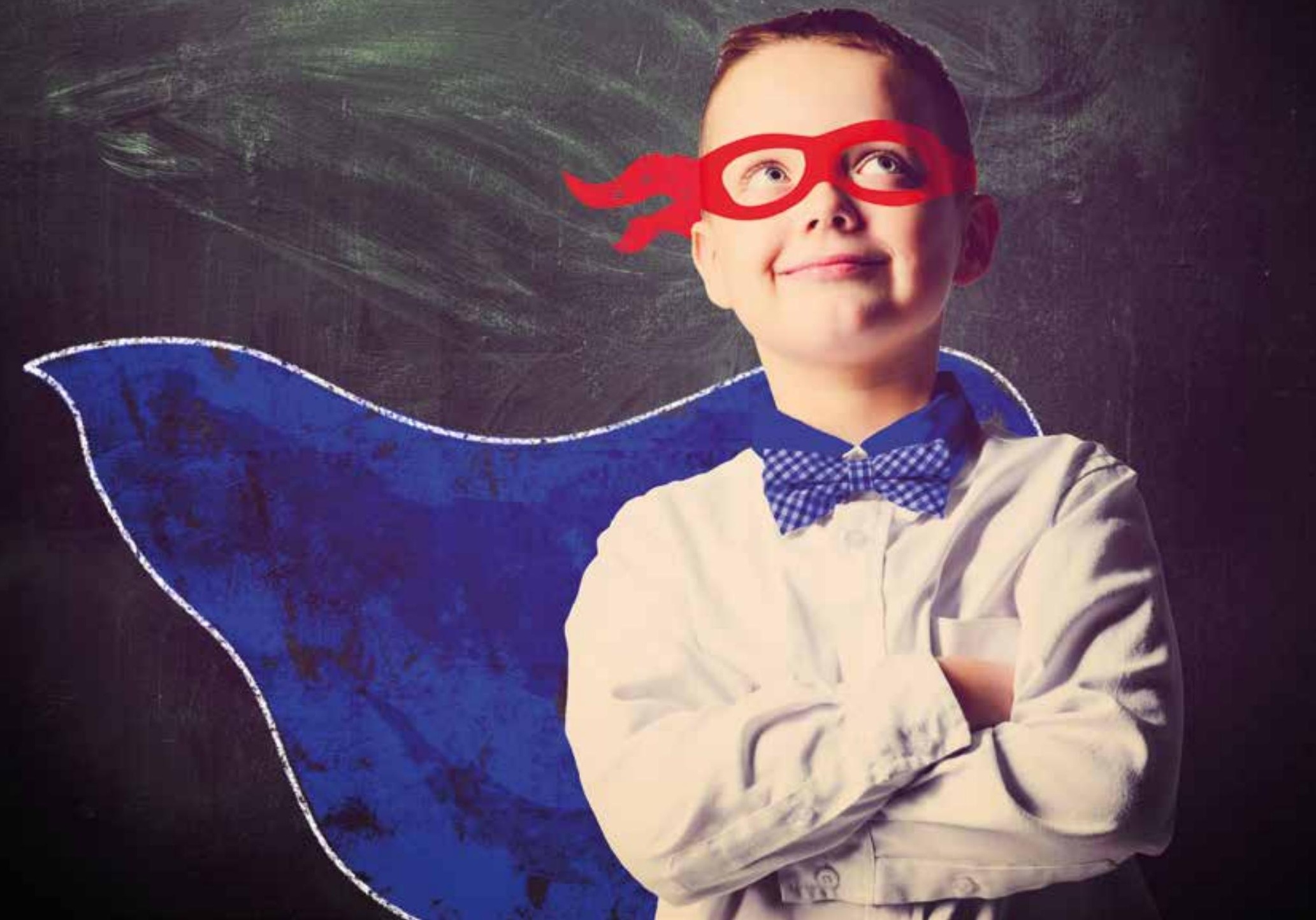




\section{Från dröm till verklighet}

Om nordiska kompetensmål och didaktiska

principer för undervisning i entreprenörskap

Anders Rasmussen och Anne Fritzner

ISBN 978-92-893-4482-1 (PRINT)

ISBN 978-92-893-4483-8 (PDF)

http://dx.doi.org/10.6027/ANP2016-710

ANP 2016:710

(C) Nordic Council of Ministers 2016

Layout: Gitte Wejnold

Omslagsfoto: SignElements.com

Foto: SignElements.com
Denna rapport är utgiven med finansiellt stöd från Nordiska ministerrådet. Innehållet i rapporten avspeglar inte nödvändigtvis Nordiska ministerrådets synpunkter, åsikter eller rekommendationer.

www.norden.org/nordpub

\section{Det nordiska samarbetet}

Det nordiska samarbetet är ett av världens mest omfattande regionala samarbeten. Det omfattar Danmark, Finland, Island, Norge och Sverige samt Färöarna, Grönland och Åland.

Det nordiska samarbetet är politiskt, ekonomiskt och kulturellt förankrat och är en viktig partner i europeiskt och internationellt samarbete. Den nordiska gemenskapen arbetar för ett starkt Norden i ett starkt Europa.

Det nordiska samarbetet ska stärka nordiska och regionala intressen och värderingar i en global omvärld. Gemensamma värderingar länderna emellan bidrar till att stärka Nordens ställning som en av världens mest innovativa och konkurrenskraftiga regioner.

\author{
Nordiska ministerrådet \\ Ved Stranden 18 \\ DK-1061 København K \\ Telefon (+45) 33960200
}

www.norden.org 


\section{Från dröm till verklighet}

Om nordiska kompetensmål och didaktiska principer för undervisning i entreprenörskap 


\section{Inledning}

Nordiska ministerrådet har arbetat i flera faser för att stärka entreprenörskapskultur- och utbildning i de nordiska länderna. Globalisering, teknisk utveckling, förändringshastighet och demografiska förändringar skapar utmaningar både för den nordiska välfärdsmodellen och för enskilda människor. Därför har det med tiden uppstått ett behov av att utbildningssystemet ska förbereda elever och studenter på ett liv där de kan vara aktiva medskapare av framtiden.

\section{Nordiska ministerrådets prisbelönta rapport} "Entrepreneurship Education in the Nordic countries"1 och i EU:s "Final Report of the Thematic Working Group on Entrepreneurship Education"2 lyfts behovet av att skapa en kompetensram som kan bygga broar mellan strategi, ledning, praxis och lärande. En kompetensram kan även bidra till att skapa progression i undervisningen och tydliggöra skillnaden mellan elever som fått undervisning i entreprenörskap och dem som inte har det. Samtidigt ska den också göra att undervisningen kan ta sin utgångspunkt i det som ska läras ut i stället för i särskilda aktiviteter eller processer. Den föreliggande kompetensramen syftar till att fylla det behovet, med hänsyn tagen till nordiska skoltraditioner och den breda förståelse av entreprenörskap som har uppstått parallellt i de nordiska länderna. Entreprenörskap i ett nordiskt skolsammanhang är inriktat på att ge eleverna färdigheter som kan användas i många olika kontexter, både privat, socialt och $\mathrm{i}$ samhället.

Kompetensramen vänder sig till en rad olika intressenter. Först och främst är den ett redskap för lärare och andra i skolsektorn som vill hitta kompetens- och lärandemål och didaktiska principer för undervisningen. Kompetensramen vänder sig också till beslutsfattare som ska utforma lagstiftning och ramar som möjliggör entreprenörskapsundervisning. Den är även avsedd för skolledare som löpande ska stödja strukturer och utforma miljöer och pedagogisk utveckling så att entreprenörskapsundervisningen integreras i grundskolan.

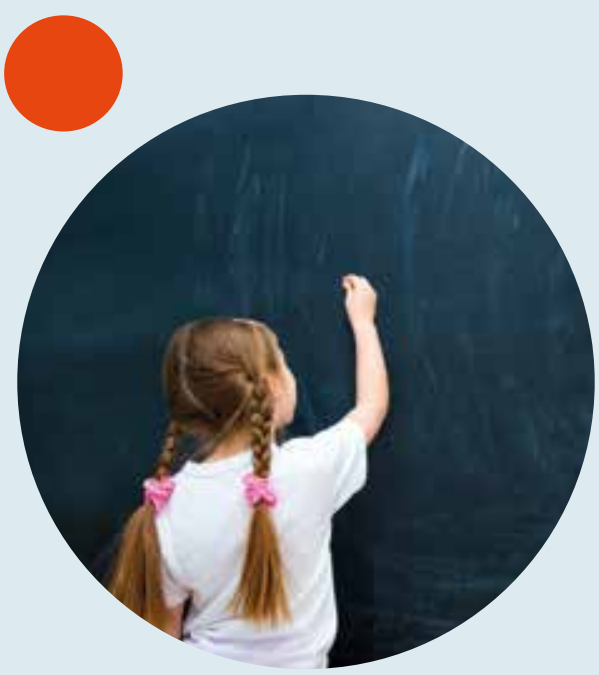




\section{De nordiska särdragen}

Trots nationella skillnader har skolorna i Norden också en rad gemensamma drag. Hit hör bildningsbegreppets betydelse, inflytandet från folkbildningsrörelsen och reformpedagogiken samt på senare tid ett starkt fokus på internationella jämförelser och evidens- och lärandemålsstyrd undervisning.

\section{Bildning}

Bildningsbegreppet har varit en del av den nordiska synen på skola och utbildning ända sedan de offentliga skolsystemen infördes. I begreppet bildning ligger tanken att det finns något som går bortom rena fackkunskaper och är knutet till den fortlöpande processen att bli en välfungerande och självständig person i ett kulturellt sammanhang. I de nordiska skolorna beskrivs bildningsidealet i skolans överordnade mål. Bildning och bildningsideal är dock inga fasta storheter utan varierar över tid under inflytande från olika politiska och kulturella kontexter och pedagogiska och filosofiska strömningar. Bildningsbegreppet är således dynamiskt och har pendlat mellan fokus på personlig utveckling och fokus på att uppnå på förhand angivna kunskapsmål ${ }^{3}$.

${ }^{1}$ Nordiska ministerrådet (2012)

${ }^{2}$ Europeiska kommissionen (2015)

${ }^{3}$ Gustavsson (1998) Dannelse i vor tid, Forlaget KLIM 


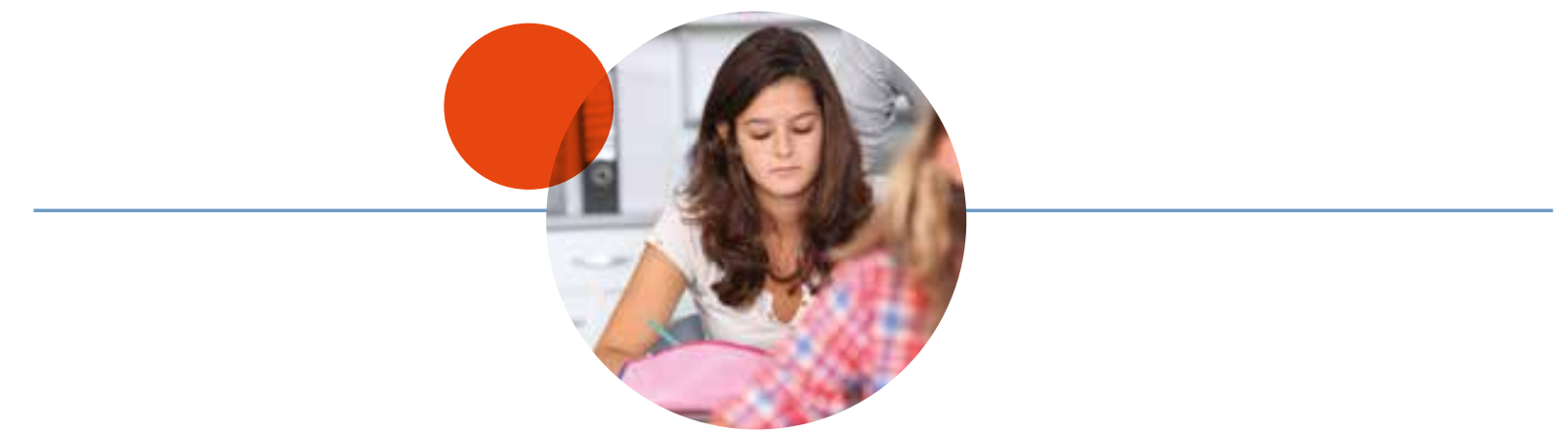

Nordens demokratier och välfärdsstater uppstod i nära samspel med ett demokratiskt bildningsideal som innebär att eleverna ska lära sig att ta ställning, handla, bidra till ett demokratiskt samhälle och agera som demokratiska medborgare. En del av bildningsbegreppet gäller förmågan till självbestämmande, socialt ansvar och att ingå i och vara medskapare av ett samhälle. Det är en syn som ligger nära den som präglar nordisk entreprenöriell bildning och den aktuella kompetensramen. En utmaning med bildningsbegreppet är att det tillskrivs olika innebörd i olika situationer och att det ofta sätts i motsättning till fackkunskap, trots att rena ämneskunskaper alltid har varit en del av bildningen. Dessutom är det ofta oklart vad det är man ska lära sig för att vara "bildad". Den aktuella kompetensramen är ett försök att konkretisera och utveckla några av de entreprenöriella bildningselement som redan finns i skolornas mål.

\section{Reformpedagogik}

Reformpedagogiken har haft stort inflytande på den nordiska synen på utbildning och lett till att den auktoritära skolan med sträng disciplin och utantillärande har försvunnit. Även om fokus i dag i hög grad ligger på ämneskunskaper och mätbarhet, är undervisningen fortsatt centrerad kring barnet och tar oftast utgångspunkt i elevernas behov och intressen. Att eleverna aktivt deltar i lärandet genom projekt-, grupp- och tvärdisciplinära arbeten är även det en del av vardagen i nordiska skolor. Tillsammans med folkbildningsrörelserna har det här gett en form av nordisk "självklarhet" som innebär att relationen mellan lärare och elev är informell och jämlik, och att hänsyn tas till elevernas motivation, lust och intressen i undervisningen ${ }^{4}$.
Det har till och med hävdats att den reformpedagogiska praxisen blivit för framgångsrik för sitt eget bästa och att problemet i dag således inte är den "ofrihet" som den frigörande pedagogiken skulle råda bot på, utan vad vi faktiskt ska använda frihet och frigörelse till ${ }^{5}$. Entreprenörskapsundervisning kan ses som en vidareutveckling av reformpedagogiska tankegångar, eftersom syftet är att stödja elevernas möjlighet att agera i samhället, sköta sina privatliv och arbeten samt kunna genomföra initiativ som skapar värde för andra kulturellt, ekonomiskt och socialt ${ }^{6}$. Entreprenörskapsundervisning är således inte frigörande i klassisk bemärkelse, utan inriktat på att stärka elevens förmåga att fritt använda de möjligheter som finns i livet och världen.

\section{Fokus på lärandemål och uppföljning.}

De senaste åren har mätbara kunskapsresultat och internationella jämförelser blivit en del av den skolpolitiska dagordningen och därmed också av de nordiska skolornas vardag. Samtidigt har forskning som visar att eleverna lär sig mer om undervisningen bygger på tydliga lärandemål och feedback fått stort genomslag ${ }^{7}$. Tillsammans har dessa faktorer gett upphov till en rad reformer av skolsystemen och de krav som ställs på skolor och lärare. Den utvecklingen har ägt rum parallellt med att strategierna för entreprenörskap införts. Problemet är att när skolämnena i allt högre grad specificeras och mäts, riskerar skolans överordnade mål - häribland de entreprenörsmässiga aspekterna - att framstå som abstrakta och svårhanterliga. Den föreliggande kompetensramen är därför ett försök att förtydliga lärandemålen för entreprenörskap så att de kan användas som utgångspunkt för undervisning, feedback och utvärdering på samma sätt som inom 


\section{Entreprenöriella kompetenser}

Kompetensramen bygger på tillgänglig internationell forskning samt på nordiska skolmål och entreprenörskapsstrategier. En referensgrupp från de fem nordiska länderna och de tre självstyrande områdena har bidragit till att säkra att ramen kan tillämpas på nationell nivå. Kompetensbegreppet är inspirerat av llleris ${ }^{8}$ och kan definieras så här:

\section{"Helhetsbetonade förnufts- och känslomässigt förankrade kapaciteter, dispositioner och potentialer som är relaterade till möjliga hand- lingsområden och realiseras genom bedömningar, beslut och handlingar i relation till kända och okända situationer."}

Ramen består således av en rad kompetenser som stöds av kunskaper, färdigheter, känslor och personliga resurser.
Kunskap och färdigheter är som utgångspunkt konkreta och om inte alltid mätbara så åtminstone observerbara och möjliga att ställa upp i en taxonomi. Annorlunda är det med de personliga och subjektiva resurserna, som inte är något man kan undervisa $i$, examinera och utvärdera. Det kan exempelvis ses som en viktig resurs att "vara uthållig", men uthållighet är inte något som det går att undervisa i. Det är något som istället måste tränas genom de metoder och aktiviteter som används $i$ undervisningen. Denna del av kompetensramen är således mer beroende av metod och didaktisk modell än de mer konkreta kunskap- och färdighetsområdena.

\section{Forskning}

Inom forskningen går meningarna isär när det gäller vilka kunskaper, färdigheter och personliga resurser som utgör entreprenöriella kompetenser. Forskarna är även oeniga om hur dessa kompetenser bäst kan utvecklas. Det finns dock ett antal områden som framstår som 
centrala, både till innehållet och i fråga om pedagogisk form ${ }^{9}$. Dessa är:

- Betoningen av handlingsaspekten och att entreprenörskapsundervisningen ska bygga på elevernas faktiska handlingar och aktiva deltagande.

- Kreativitet och förmågan att se, känna och skapa möjligheter samt förmågan till problemlösning, divergent tänkande och att kunna experimentera med olika kunskapsformer.

- Kunskap om, förståelse av och interaktion med kultur, omvärld och externa parter

- Elevers subjektiva tro på och tillit till sina egna möjligheter och resurser att kunna agera i världen och förverkliga drömmar och visioner, häribland uthållighet och förmågan att handla i osäkra kontexter

\section{Nordiska strategier och bildningsmål}

I de nordiska ländernas överordnade skolmål och de nationella entreprenörskapsstrategierna ingår en lång rad kunskaps-, färdighets- och kompetensmål med direkt eller indirekt koppling till entreprenörskap. Några av områdena gäller yttre företeelser som eleverna ska känna till: "kreativa arbetsmetoder, affärsutveckling, ekonomi, projektstyrning, nätverk", eller som de ska kunna hantera: "ta initiativ, ansvar, omsätta idéer i handling, beslutsfattande, kommunikation, samarbete och problemlösning”. Andra områden gäller inre resurser, alltså känslomässiga eller personliga egenskaper, till exempel: "Vara öppen för möjligheter, uthållighet och tålamod, nyfikenhet, självtillit, kreativitet och mod at ta risker, använda fantasin för att överskrida nuvarande gränser". Därtill finns en rad normativa eller etiska punkter som att: "Bidra till en hållbar framtid".

\section{Referensgruppens bidrag}

Referensgruppen kom med en rad bidrag som rör kunskaper, färdigheter och kompetenser. Här rör det sig, precis som i de överordnade beskrivningarna av skolans mål, om mycket varierande kunskaps-, färdighets- och kompetensmål som gäller såväl yttre som inre företeelser, exempelvis: "Jag själv som entreprenör, hur samhället är uppbyggt och fungerar, presentera mig själv och mina idéer, se behov och komma med lösningar, kreativt hantera osäkerhet, identifiera möjligheter och vara proaktiv, kunskaper om lokalsamhället, landet och världen."

Det finns också flera olika fokus, som "progression och taxonomi" (DK), en viss form av "pedagogiskt entreprenörskap" $(\mathrm{N})$ och en särskild modell för "entreprenöriellt lärande” (S). De olika infallsvinklarna visar att de nordiska ländernas förhållandevis likartade strategier har resulterat i aktiviteter och praxis med stor mångfald.

\footnotetext{
${ }^{8}$ Illeris (2013) Kompetence - Hvad, hvorfor, hvordan?, Samfundslitteratur,

${ }^{9}$ Nybye \& Rasmussen (2013) Progressionsmodel for innovations- og entreprenørskabsundervisning, Fonden for Entreprenørskab
} 


\section{Kompetensram}

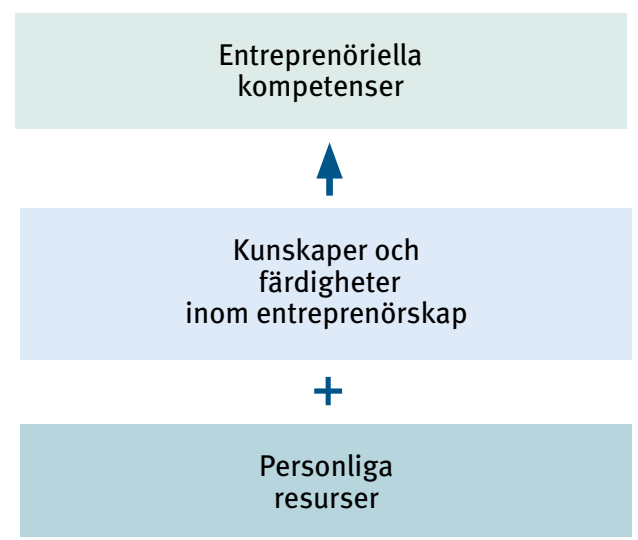

Utifrån bidrag och uttalanden från forskare, nordiska skolmål och referensgruppen går det att urskilja fyra kompetenser, varav tre bygger på kunskap och färdigheter. Det fjärde området gäller personliga resurser och fungerar som en grund på vilken övriga kompetenser kan sättas i spel. För att exempelvis utföra handlingar i världen behövs mod, ansvar, acceptans för misstag och så vidare. Omvänt leder personliga resurser i sig inte automatiskt till en kvalificerad handling eller till entreprenöriell kompetens och bildning.

1. Handlingskompetens: Planera, strukturera, utföra, samarbeta, kommunicera och hantera ekonomi och resurser

2. Kreativitetskompetens: Att skapa, överskrida, tänka divergent, tänka på tvären, formulera drömmar, känna, experimentera, lösa problem och värdera

3. Omvärldskompetens: Kunskap om kulturformer, globalisering, samhällets beskaffenhet, affärsförståelse, sociala förhållanden, nätverk, förmågan att uppfatta och navigera i en komplex samtid. Hur vi uppfattar vår värld och våra omgivningar, vilka intryck vi är mottagliga för
4. Personliga resurser: Mod, självtillit, uthållighet, hantering av komplexitet och osäkerhet, acceptans för misstag, initiativ, ansvar och självständighet

Entreprenöriella kompetenser utvecklas alltså som en produkt av kunskaper och färdigheter inom handling, kreativitet och omvärld, med en rad personliga resurser som förutsättning.

Kompetensramen är utformad på tre nivåer: årskurs $3 /$ inskolning, årskurs 6/mellersta årskurserna och årskurs 9/utskolning. De kunskaper, färdigheter och kompetenser som anges på de tre nivåerna är uttryck för en idealbild och ett slutmål. 


\section{Årskurs 3}

\begin{tabular}{|c|c|c|c|c|c|}
\hline \multicolumn{2}{|c|}{$\begin{array}{l}\text { Handlingskompetens } \\
\text { Eleven kan samarbeta kring uppgifter } \\
\text { och med stöd genomföra enkla projekt i } \\
\text { skolan och i närmiljön }\end{array}$} & \multicolumn{2}{|c|}{$\begin{array}{l}\text { Kreativ kompetens } \\
\text { Eleven kan arbeta experimenterande och } \\
\text { undersökande i enkla kreativa processer } \\
\text { och kan förhålla sig till resultaten } \\
\text { genom användning av grundläggande } \\
\text { ämneskunskaper }\end{array}$} & \multicolumn{2}{|c|}{$\begin{array}{l}\text { Omvärldskompetens } \\
\text { Eleven har en spirande förståelse av sin } \\
\text { egen identitet och kulturella bakgrund } \\
\text { och kan orientera sig i enkla lokala } \\
\text { kontexter }\end{array}$} \\
\hline Färdighet, kan & Kunskap om & Färdighet, kan & Kunskap om & Färdighet, kan & Kunskap om \\
\hline $\begin{array}{l}\text { Delta i enkla } \\
\text { projekt } \\
\text { Ingå i enkla } \\
\text { samarbets- } \\
\text { relationer } \\
\text { Presentera egna } \\
\text { resultat och } \\
\text { produkter i skola } \\
\text { och närmiljö } \\
\text { Ta kontakt med } \\
\text { personligt nätverk } \\
\text { Arbeta med enkla } \\
\text { visualiseringar och } \\
\text { modeller } \\
\text { Skapa } \\
\text { utställningar av } \\
\text { gemensamma } \\
\text { projekt }\end{array}$ & $\begin{array}{l}\text { Planering och } \\
\text { målsättning } \\
\text { Att samarbeta } \\
\text { med andra } \\
\text { Kommunikation } \\
\text { och enkla pres- } \\
\text { entationsformer } \\
\text { Personligt nätverk } \\
\text { Representationer } \\
\text { och modeller }\end{array}$ & $\begin{array}{l}\text { Använda fantasi } \\
\text { och kreativitet } \\
\text { i samband med } \\
\text { undervisning och } \\
\text { aktiviteter } \\
\text { Kombinera olika } \\
\text { kunskaps-om- } \\
\text { råden } \\
\text { Leka med } \\
\text { kunskaper } \\
\text { Delta i enkla } \\
\text { idégenererings- } \\
\text { processer } \\
\text { Delta i samtal om } \\
\text { bedömning av } \\
\text { idéer } \\
\text { Använda begrepp } \\
\text { för sinnesintryck } \\
\text { och bildspråk }\end{array}$ & $\begin{array}{l}\text { Fantasi och } \\
\text { kreativitet } \\
\text { Enkla kreativa } \\
\text { processer } \\
\text { Enkel idé- } \\
\text { generering } \\
\text { Sinnesintryck och } \\
\text { enkel estetik }\end{array}$ & $\begin{array}{l}\text { Beskriva den egna } \\
\text { kulturen } \\
\text { Använda penga- } \\
\text { begreppet i enkla } \\
\text { matematiska } \\
\text { beräkningar } \\
\text { Samtala om } \\
\text { möjligheter och } \\
\text { utmaningar i } \\
\text { närmiljön }\end{array}$ & $\begin{array}{l}\text { Egen och andras } \\
\text { kulturer } \\
\text { Pengabegreppet } \\
\text { Fritids- och } \\
\text { arbetsliv } \\
\text { Företag och } \\
\text { institutioner i } \\
\text { närmiljön }\end{array}$ \\
\hline & & $\begin{array}{r}\text { PERSONL } \\
\text { Mod att u } \\
\text { Tilltro till sin } \\
\text { initiativ med stöd f } \\
\text { lållighet och tålamo } \\
\text { eptans för egna mis } \\
\text { Hantera osäkerhet } \\
\text { Fokusera på upp }\end{array}$ & $\begin{array}{l}\text { RESURSER } \\
\text { na sig själv } \\
\text { gna förmågor } \\
\text { lärare och andra vux } \\
\text { nder kortare tidsrym } \\
\text { g och missuppfattnir } \\
\text { der korta tidsrymder } \\
\text { er och utmaningar }\end{array}$ & & \\
\hline
\end{tabular}




\section{Årskurs 6}

\begin{tabular}{|c|c|c|c|c|c|}
\hline \multicolumn{2}{|c|}{$\begin{array}{l}\text { Handlingskompetens } \\
\text { I samarbete med andra kan eleven ta initi- } \\
\text { ativ till, planera, organisera och genomfö- } \\
\text { ra enkla projekt i en konkret kontext }\end{array}$} & \multicolumn{2}{|c|}{$\begin{array}{l}\text { Kreativ kompetens } \\
\text { Eleven kan arbeta självständigt, experi- } \\
\text { menterande och undersökande i kreativa } \\
\text { processer och bedöma resultaten utifrån } \\
\text { ämneskunskaper och estetiska kriterier }\end{array}$} & \multicolumn{2}{|c|}{$\begin{array}{l}\text { Omvärldskompetens } \\
\text { Eleven kan mot bakgrund av förståel- } \\
\text { sen av sin egen identitet och kulturella } \\
\text { bakgrund orientera sig i olika tekniska, } \\
\text { ekonomiska, kulturella och sociala } \\
\text { kontexter }\end{array}$} \\
\hline Färdighet, kan & Kunskap om & Färdighet, kan & Kunskap om & Färdighet, kan & Kunskap om \\
\hline $\begin{array}{l}\text { Beskriva osäkerhet } \\
\text { i samband med } \\
\text { projekt } \\
\text { Aktivt ingå i projekt } \\
\text { Använda personligt } \\
\text { nätverk } \\
\text { Ingå i samarbets- } \\
\text { relationer } \\
\text { Presentera resultat } \\
\text { och projekt }\end{array}$ & $\begin{array}{l}\text { Enkel } \\
\text { projektstyrning, } \\
\text { planering, risker } \\
\text { och resurser } \\
\text { Enkla samarbets- } \\
\text { former } \\
\text { Kommunikation, } \\
\text { presentations- } \\
\text { former och verktyg } \\
\text { Personligt och } \\
\text { skolbaserat } \\
\text { nätverk } \\
\text { Modeller, symbo- } \\
\text { ler och visuella } \\
\text { uttryck }\end{array}$ & $\begin{array}{l}\text { Kombinera olika } \\
\text { ämnesrelaterade } \\
\text { kunskaps- } \\
\text { områden } \\
\text { Experimentera } \\
\text { med kunskap } \\
\text { Delta i ämnes- } \\
\text { inriktad problem- } \\
\text { lösning } \\
\text { Arbeta i kreativa } \\
\text { processer } \\
\text { Delta i idé- } \\
\text { generering } \\
\text { Samtala om be- } \\
\text { dömning av idéer } \\
\text { Använda begrepp } \\
\text { för sinnesintryck } \\
\text { Samtala om dröm- } \\
\text { mar om den när- } \\
\text { maste framtiden }\end{array}$ & $\begin{array}{l}\text { Fantasi och krea- } \\
\text { tivitet i samband } \\
\text { med olika ämnes- } \\
\text { områden } \\
\text { Kreativa processer } \\
\text { Former för idé- } \\
\text { generering } \\
\text { Sinnesintryck } \\
\text { och estetik }\end{array}$ & $\begin{array}{l}\text { Jämföra kulturer } \\
\text { Samtala om } \\
\text { möjligheter och } \\
\text { problem i världen } \\
\text { Diskutera egen } \\
\text { förståelse av } \\
\text { världen } \\
\text { Lägga upp enkla } \\
\text { budgetar } \\
\text { Beskriva ekonomi } \\
\text { och andra resur- } \\
\text { ser i samhället } \\
\text { Beskriva hur ett } \\
\text { företag fungerar }\end{array}$ & $\begin{array}{l}\text { Skillnad på } \\
\text { kulturer } \\
\text { Samhällets } \\
\text { uppbyggnad och } \\
\text { organisation } \\
\text { Ekonomi och } \\
\text { olika resurser } \\
\text { Skola, fritid och } \\
\text { arbetsliv } \\
\text { Företag och } \\
\text { institutioner i } \\
\text { lokalområdet }\end{array}$ \\
\hline
\end{tabular}

\section{PERSONLIGA RESURSER}

Mod och vilja att utmana sig själv och sina kamrater

Ansvar för egna och gemensamma projekt

Tilltro till sina egna förmågor

Ta initiativ tillsammans med andra

Förändringsvilja när det gäller egna arbetsformer, åsikter och synpunkter

Uthållighet och tålamod under längre tidsrymder

Acceptans för egna och andras misstag och missuppfattningar

Hantera osäkerhet under korta tidsrymder

Fokusera på uppgifter och utmaningar under längre tid 


\section{Årskurs 9}

\section{Handlingskompetens}

I samarbete med andra kan eleven ta initiativ till, planera, ta ansvar för, leda, organisera och genomföra projekt i en konkret kontext

\section{Kreativ kompetens}

Eleven kan arbeta självständigt, tålmodigt, experimenterande och undersökande i kreativa processer och bedöma resultaten utifrån ämneskunskaper, erfarenheter och estetiska kriterier

\section{Omvärldskompetens}

Eleven kan mot bakgrund av förståelsen av sin egen identitet och kulturella bakgrund orientera sig i och bedöma olika tekniska, ekonomiska, kulturella och sociala kontexter

\begin{tabular}{l}
\hline Färdighet, kan \\
\hline $\begin{array}{l}\text { Hantera projekt } \\
\text { tillsammans med } \\
\text { andra }\end{array}$
\end{tabular}

Bedöma osäkerhet i samband med projekt

Ingå i olika slags samarbetsrelationer

Ta kontakt utanför sitt personliga nätverk

\section{Bygga upp och} använda eget nätverk

Presentera resultat och projekt för en specifik målgrupp

Kunskap om
$\begin{aligned} & \text { Projektstyrning } \\ & \text { planering, int } \\ & \text { senter, risker } \\ & \text { resurser }\end{aligned}$
Samarbets-
former och
processer

\section{Personliga och} professionella nätverk

Kommunikation, presentations-former och verktyg

\begin{tabular}{|l}
\hline Färdighet, kan \\
$\begin{array}{l}\text { Kombinera olika } \\
\text { ämnesrelaterade } \\
\text { kunskaps-områd }\end{array}$
\end{tabular}

\section{Experimentera med}

information och ämneskunskaper

Arbeta med ämnesspecifik problemlösning

\section{Strukturera idé- genererings- processer}

\section{Arbeta i olika} kreativa processer

Diskutera bedömningar av idéer

Använda begrepp för sinnesintryck i relation till ämnesrelaterade kunskaper

Formulera drömmar och visioner för framtiden

\begin{tabular}{|c|c|}
\hline Kunskap om & Färdighet, kan \\
\hline $\begin{array}{l}\text { Fantasi och kreati- } \\
\text { vitet i samhället }\end{array}$ & $\begin{array}{l}\text { Beskriva och } \\
\text { jämföra kulturer }\end{array}$ \\
\hline Kreativa processer & $\begin{array}{l}\text { Beskriva möjlig- } \\
\text { heter och problem }\end{array}$ \\
\hline $\begin{array}{l}\text { Olika idégenere- } \\
\text { rings-former }\end{array}$ & med globalisering \\
\hline
\end{tabular}

rings-former

Sinnesintryck och estetik

Kreativitet $\mathrm{i}$

förhållande till ämneskunskaper
Lägga upp enkla budgetar och redovisningar

Analysera och beskriva resurser

Beskriva enkla affärsmodeller Utmana befintliga förståelser av världen

\section{Kunskap om}

Olika kulturer

Globalisering och konsekvenser

Samhällets uppbyggnad, organisation, problem och möjligheter

Arbetsliv och karriär-

möjligheter

Ekonomi och resurser

\section{PERSONLIGA RESURSER}

Mod och vilja att utmana sig själv och andra

Ansvar för egna och gemensamma projekt Tilltro till sitt eget omdöme, sina förmågor och sin potential

Ta initiativ självständigt och tillsammans med andra

Förändringsvilja när det gäller rådande uppfattningar och vanor

Uthållighet och tålamod under långa och avbrutna tidsrymder

Acceptans för och förmåga att lära av egna och andras misstag och missuppfattningar

Överblicka osäkra och komplexa uppgifter

Behålla fokus på avbrutna uppgifter och projekt över längre tid 


\section{Entreprenöriella kompetenser i den pedagogiska praktiken}

Entreprenörskap är inget ämne i nordiska grundskolor. Entreprenöriella kompetenser måste därför utvecklas inom ramen för de befintliga ämnena och som särskilda entreprenöriella undervisningsförlopp. Det betyder att lärarna måste kunna integrera utvecklingen av entreprenöriella kompetenser i skolans ämnen, så att entreprenörskap blir en del av skolans vardag. Samtidigt måste skolorna se till att eleverna får möjlighet att delta $i$ sammanhängande entreprenöriella förlopp där kompetenserna kommer till användning, gärna i en värdeskapande tillämpning.

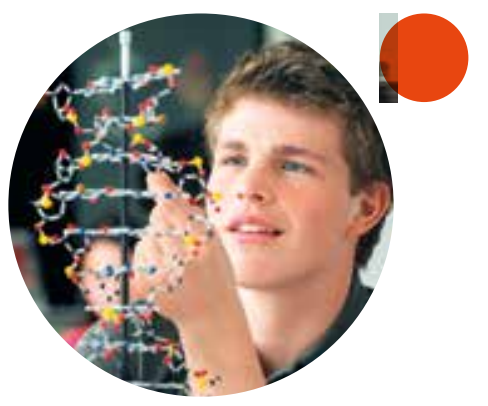




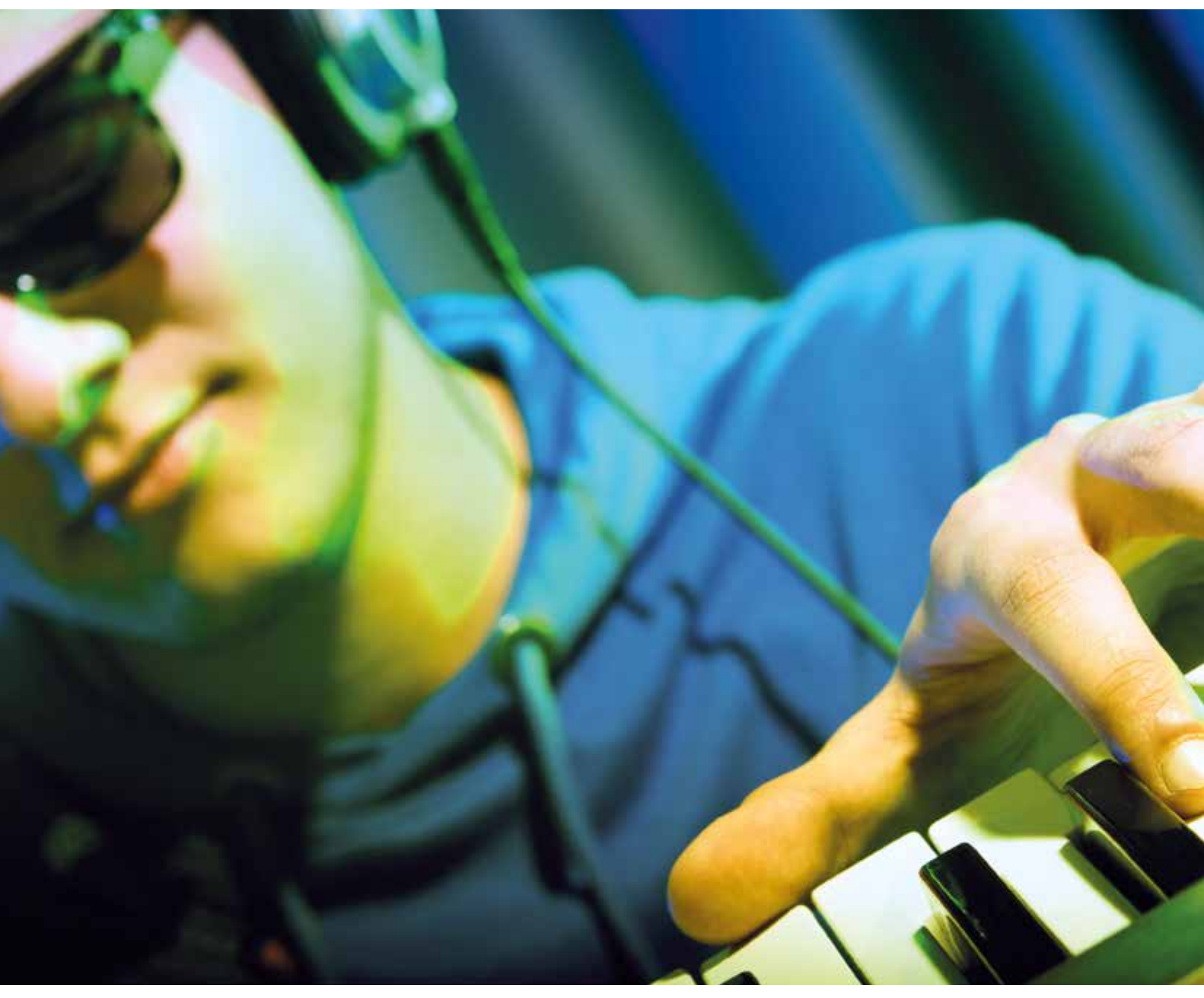




\section{Didaktiska principer}

Nedan följer en förteckning över en rad didaktiska principer som kan stötta utvecklingen av elevernas kompetenser och deras personliga resurser. Didaktik handlar om kopplingen mellan undervisningens mål, innehåll och metod och bidrar till att eleverna lär sig det önskade och får stöd för fortsatt utveckling och lärande. Didaktiska principer är således redskap som lärarna kan använda i planeringen av undervisningen och påverkar undervisningens ramar, organisation och genomförande. Tanken bakom principerna är att de ska vara oberoende av årskurs, nivå och ämne samt att de ska underlätta överföringen från kompetensmål till praktik och omvänt. Principerna kan tillämpas en eller flera åt gången, men det är förmodligen varken lämpligt eller möjligt att tillämpa alla principerna på en gång.

\section{Principer som stödjer utvecklingen av handlingskompetens}

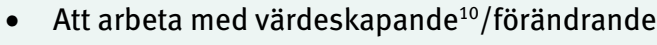
aktiviteter

- Att arbeta med involvering och elevdelaktighet

- Att ge eleverna ansvar för aktiviteter

- Att tillämpa kunskaper och färdigheter i olika kontexter

- Att ta avstamp i olika kontexter för aktiviteter

- Att använda nätverk och relationer

- Att stimulera varierande samarbetsformer

- Att stimulera varierande presentationsformer

- Att stimulera reflexion kring handling

\footnotetext{
${ }^{10}$ Värdeskapandet skiljer entreprenöriella undervisningsförlopp från andra processbaserade undervisningsformer, till exempel problemorienterad projektundervisning eller ämnesarbete. Med värdeskapande menas att aktiviteten skapar värde åt andra, vid sidan av elevernas eget lärande. Aktiviteterna gör med andra ord ett slags nytta i världen, antingen reellt genom konkreta aktiviteter eller potentiellt som planer, modeller osv.
}

\section{Principer som stödjer utvecklingen av kreativa kompetenser}

- Att arbeta med experimenterande aktiviteter

- Att skapa bedömningsfria perioder

- Att arbeta med skapande aktiviteter

- Att erbjuda tid för fördjupning

- Att formulera öppna/omöjliga uppgifter

- Att överraska och föra in det oväntade

- Att involvera flera sinnen

- Att bjuda in till reflektion kring fantasi och kreativitet 


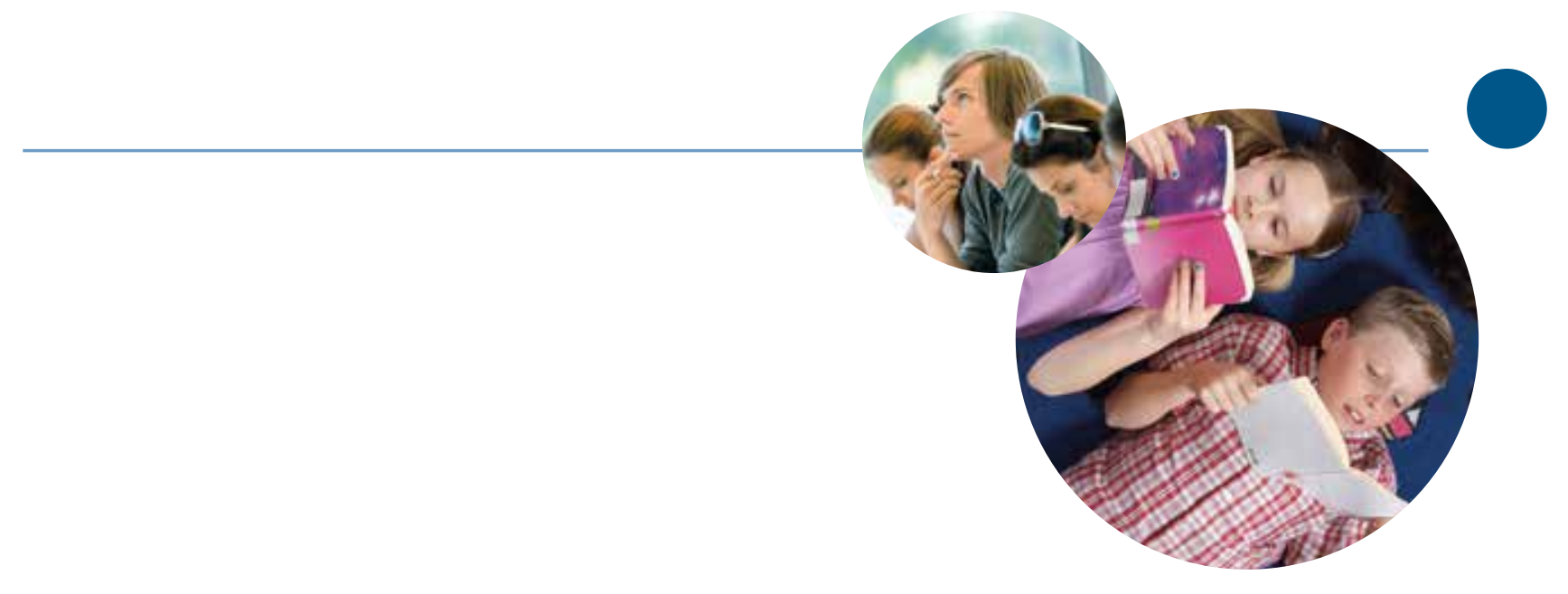

\section{Principer som stödjer utvecklingen} av omvärldskompetens

- Att stimulera nyfikenhet och frågor

- Att involvera aktuella teman

- Att sätta ämneskunskaper, information och färdigheter i perspektiv

- Att involvera sociala, ekonomiska och kulturella kontexter

- Att säkra interaktion mellan individ, skola och omvärld

- Att inhämta information och feedback från omvärlden

- Att formulera världen som möjlighet

- Att stimulera reflexion kring skolans omvärld

\section{Principer som stödjer utvecklingen} av personliga resurser

- Att säkra framgångserfarenheter

- Att erbjuda lagom utmanande uppgifter

- Att skapa utrymme för bekräftelse

- Att arbeta medvetet med osäkerhet

- Att arbeta med involvering och elevdelaktighet

- Att stötta och vägleda

- Att bjuda in till reflexion kring personliga resurser 


\section{Exempel på tillämpning av de didaktiska principerna}

Exemplen har utarbetats av personer som är verksamma i skolan och har testats på nordiska skolor. Ämnen och överordnade kompetensområden har hämtats från "gemensamma mål" för undervisningen. Undervisningsförloppen är allmänna och bidrar genom tillämpningen av de didaktiska principerna inte bara till ämnesmålen utan även till utvecklingen av entreprenöriella kompetenser.

\section{Biologisk mångfald, årskurs 3}

I förloppet ingår ämnesmål från ämnet "naturkunskap/ teknik", häribland kompetensområdena "utforskande" och "kommunikation".

Förloppet börjar med en introduktion till begreppet biologisk mångfald. Sedan ska eleverna självständigt utforska olika databaser om djur och habitater (principen om att inhämta information och feedback från omvärlden). Därefter planerar elever och lärare gemensamt en utflykt (principen om elevdelaktighet och involvering), där eleverna i små grupper letar efter djur i närmiljön (principen om att stimulera nyfikenhet och frågor) med särskilt fokus på att bekanta sig med habitater och fauna i närområdet (principen om att involvera kontexter).

Eleverna ska sedan välja ett visst djur och ta reda på mer om det (principen om att ge plats åt fördjupning), göra skisser och teckningar (principen om att involvera flera sinnen) för att göra en presentation av ämnet (principen om att arbeta medvetet med osäkerhet). Under presentationerna ska de andra eleverna komma med beröm och förslag på förbättringar och fortsatt arbete (principen om att skapa utrymme för bekräftelse). Som avslutning diskuteras förslag på hur eleverna kan bidra till att värna den biologiska mångfalden i sin närmiljö (principen om att formulera världen som möjlighet).

\section{Kompismöbel, årskurs 6}

I förloppet ingår ämnesmål från ämnet "hantverk och design", häribland kompetensområdena "bearbetning", "material" och "design".

Eleverna får i uppgift att göra en "möbel" som passar för att sitta tillsammans med vänner. Förloppet börjar med diskussioner och en lärarledd genomgång av möblers historia och bakgrund samt om designutveckling, där möbler både är bruksföremål, varor och konstverk (principen om att sätta ämneskunskaper, information och färdigheter i perspektiv). Eleverna ska sedan besöka en möbelbutik (gärna i verkligheten men annars virtuellt) och undersöka olika designer, material och egenskaper (principen om att inhämta information och kunskap från omvärlden/principen om att säkra interaktion mellan individ, skola och omvärld). De väljer en möbel som de ska beskriva i skrift (principen om att tillämpa kunskap och färdigheter i olika kontexter). Sedan arbetar eleverna med att utveckla idéer till egna möbler med kriteriet att möbeln ska fungera som en ram för samvaron med vänner och att kunna lära sig tillsammans (principen om öppna/omöjliga uppgifter) Därefter bygger eleverna modeller av möblerna med ett fast storleksförhållande (principen om att involvera flera sinnen) och ger varandra konstruktiv feedback (principen om att skapa bedömningsfria perioder). Som avslutning ska eleverna undersöka hur modellen kan bli till en konkret produkt och hur man kan skapa et företag utifrån en produktion (principen om att stimulera reflexion kring handling). 


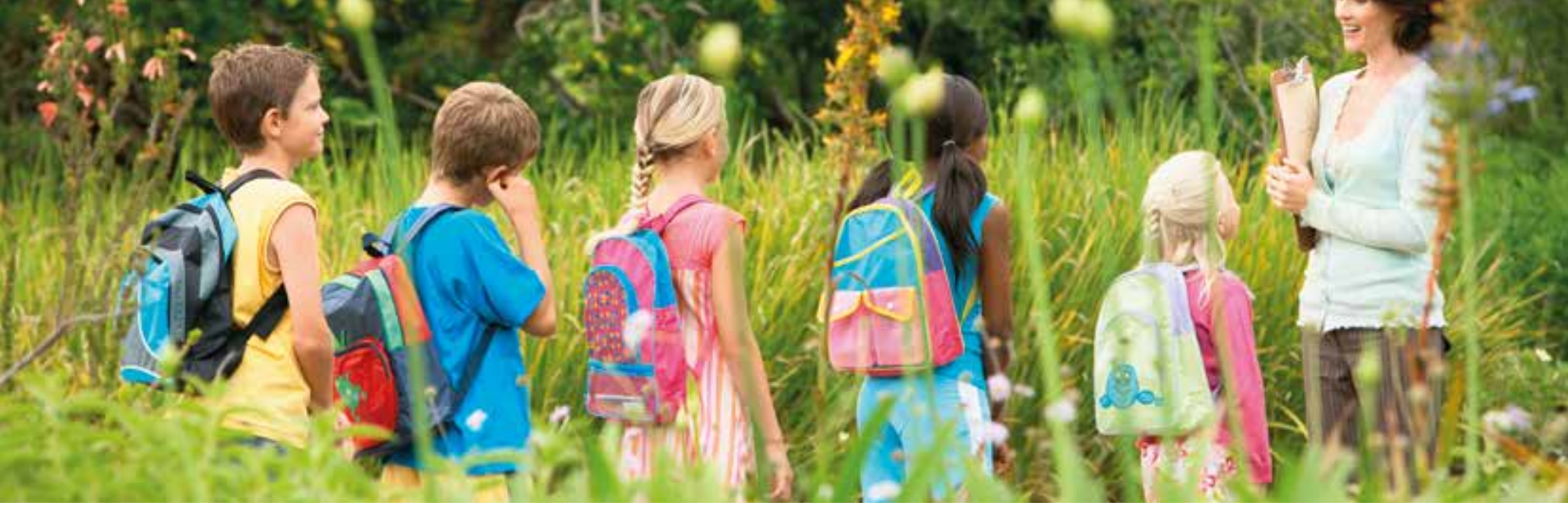

Som avslutning förbereder och övar eleverna på en säljpresentation för produkten.

\section{Tillämpad matematik, årskurs 8}

I förloppet ingår ämnesmål för ämnet matematik, häribland kompetensområdet "matematisk kompetens".

Inledningsvis delas eleverna in i mindre grupper och varje grupp får ett vardagsföremål, t.ex. en mjölkkartong, ett cykelhjul, ett glas, en tidning (principen om att överraska och föra in det oväntade). Eleverna får sedan en uppgift som går ut på att få ut så mycket matematik det går ur föremålet de tilldelats (principen om öppna) omöjliga uppgifter, principen om att arbeta med experimenterande aktiviteter). Eleverna arbetar självständigt med uppgiften och läraren utmanar, kommenterar och stöttar eleverna under arbetet (principen om att vägleda och stödja).

Mot bakgrund av sina resultat utarbetar eleverna matematiska uppgifter åt de andra grupperna, varpå grupperna byter uppgifter och föremål. Avslutningsvis jämför grupperna sina resultat och uträkningar och lämnar feedback på arbetet (principen om att skapa utrymme för bekräftelse).

\section{Reklam, årskurs 9}

I förloppet ingår ämnesmål för danska, häribland kompetensområdena "framställning", "tolkning" och "kommunikation".

Som inledning ska eleverna undersöka konkret reklam i närmiljön, ta bilder av den och sedan analysera den utifrån modeller och begrepp som används i ämnesundervisningen (principen om att stimulera nyfikenhet och frågor). Eleverna ska därefter göra en strukturerad intervju med avsändaren/företaget (principen om medveten osäkerhet). Eleverna utarbetar därefter olika förslag (principen om att arbeta med experimenterande aktiviteter) på annan reklam/logotyper för de undersökta företagen (principen om att arbeta med värdeskapande/ förändrande aktiviteter). Sedan ordnas en utställning där eleverna presenterar information och produkter för en yrkesperson som utvärderar produkterna och ger dem feedback (principen om att säkra interaktion mellan individ, skola och samhälle). Förloppet avslutas med ett gemensamt samtal och reflexion över förloppet, kontakten med omvärlden och ämneslärande (principen om att bjuda in till reflexion). 


\section{norden}

\section{Nordiska ministerrådet}

\section{Ved Stranden 18}

DK-1061 Copenhagen K

www.norden.org

Nordiska ministerrådet har arbetat i flera faser för att stärka entreprenörskapskultur och -utbildning i de nordiska länderna. Kompetensramen vänder sig till en rad olika intressenter. Först och främst är den ett redskap för lärare och andra i skolsektorn som vill hitta kompetens- och lärandemål och didaktiska principer för undervisningen.

Kompetensramen vänder sig också till beslutsfattare som ska utforma lagstiftning och ramar som möjliggör entreprenörskapsundervisning. Den är även avsedd för skolledare som löpande ska stödja strukturer och utforma miljöer och pedagogisk utveckling så att entreprenörskapsundervisningen integreras i grundskolan.

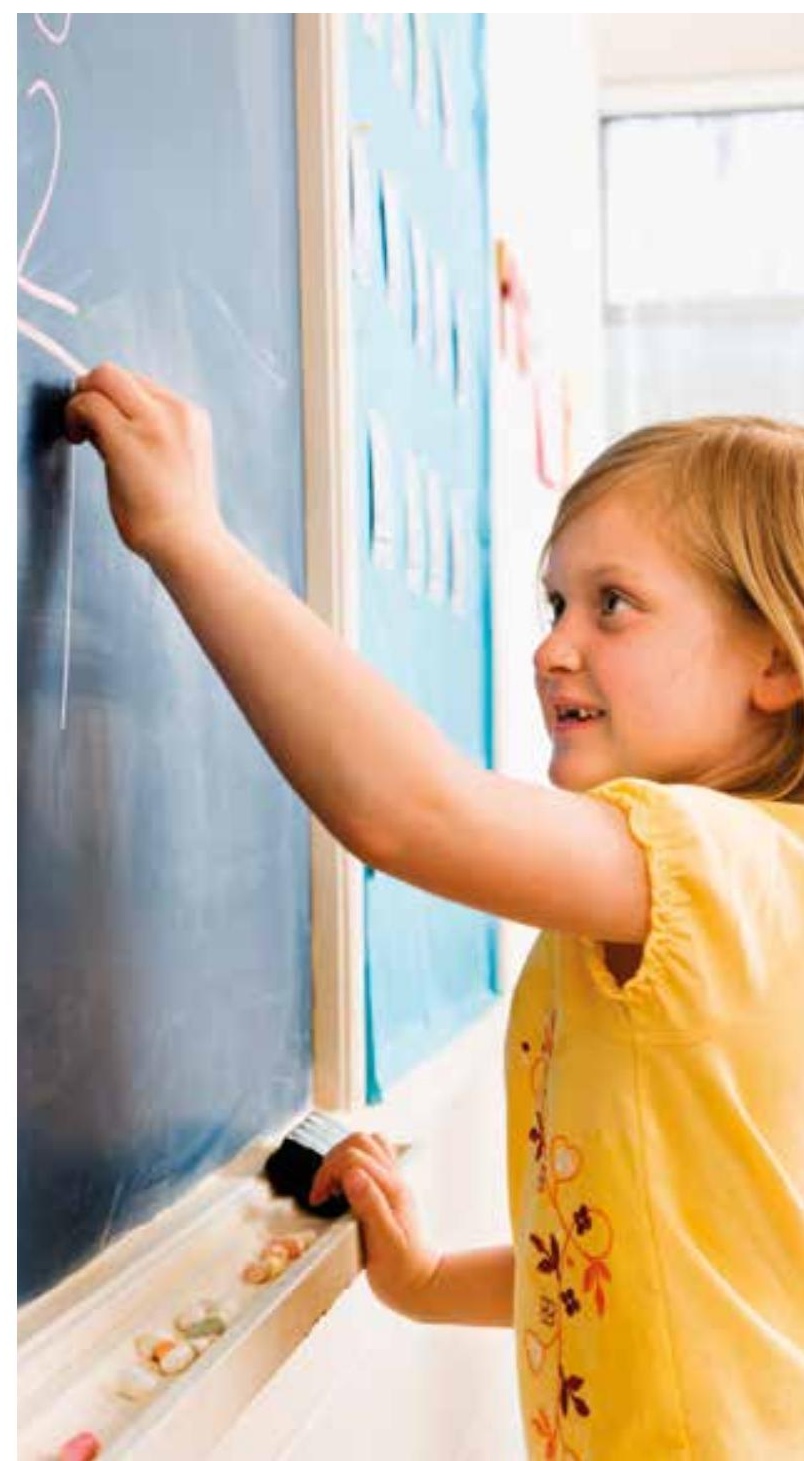

